Diabetologia $7,423-430(1971)$

(C) by Springer-Verlag 1971

\title{
Immunohistological Demonstration of Insulin in Islets of Langerhans after Stimulation of Insulin Secretion by Glucose, Sulphonylureas and Insulin Antibodies
}

\author{
P.A. Bürkle, G. Hemm, V. Huber and K. FederdiN \\ Section of Clinical Immunology and Department of Endocrinology and Metabolism, Center of Internal Medicine and \\ Pediatries, University of Ulm, Germany
}

Received: July 28, 1971, accepted: August 12, 1971

\begin{abstract}
Summary. The immunohistological detection of insulin in whole pancreatic tissue and isolated islets was studied, using cryostat sections, freeze-dried material and in formalin-fixed tissue. Cryotomy produces unsatisfactory results and can only be used as a screening procedure. The freeze-drying technique followed by paraffin embedding is time consuming, but possesses an advantage in that it best guards the natural morphological rela. tionships in cells and tissue. - The results of experiments designed to determine the immunohistologically-provable content of insulin in the islets of Langerhans of rats by means of various stimulants to insulin secretion are reported. Intravenously injected glucose in high concentration $(10 \mathrm{~g} / \mathrm{kg})$ does not lead to an immunohistologically. provable decrease in the insulin content of the beta cells, after either 2,4 or $24 \mathrm{~h}$. During the first $6 \mathrm{~h}$ following a single intravenous medication of tolbutamide $(500 \mathrm{mg} / \mathrm{kg})$ or of glibenclamide $(1 \mathrm{mg} / \mathrm{kg})$ there is no decrease in the immunofluorescence of the beta cells. The decrease, apparent after $8 \mathrm{~h}$, becomes more clear in a wide range of cells after $12 \mathrm{~h}$, and has reached its climax after $24 \mathrm{~h}$. At this time, nearly all of the cells of the islet are degranulated except those in the periphery. On the contrary, $5 \mathrm{~h}$ following intravenous injection of insulin antibodies, an almost total decrease in immunohistologically-provable insulin can be observod.
\end{abstract}

Démonstration histoimmunologique de l'insuline dans les îlots de Langerhans après stimulation par glucose, sulfonylurées et par anticorps anti-insuline

Résumé. Nous avons comparé trois techniques histoimmunologiques différentes chez le rat sur les cellules bêta du pancréas: les coupes après congélation de tissus frais, la méthode de congélation-dessiccation et la méthode avec du matériel fixé à la formaline. La méthode des coupes après congélation de tissus trouve une limitation dans la difficulté d' obtenir de bonnes préparations cytologiques. La méthode de congélation-dessiccation offre de nombreux avantages, p.ex. l'immobilisation instantanée et définitive des constituants des tissus et le fait que les changements chimiques dans les tissus sont réduits au minimum, mais elle exige beaucoup de temps. - Nous avons montré l'effet de la tolbutamide et de la glibenclamide sur les cellules bêta avec la méthode de fixation à la formaline. In vivo, l'administration intra-veineuse de glucose $(10 \mathrm{~g} / \mathrm{kg})$ ne produisait pas de dégranulation des cellules B après 2, 4 et $24 \mathrm{~h}$. En utilisant une seule injection de tolbutamide $(500 \mathrm{mg} / \mathrm{kg})$ et de glibenclamide
(1 $\mathrm{mg} / \mathrm{kg}$ ) il n'y avait pas de diminution de la fluorescence pendant les premières $6 \mathrm{~h}$. Par contre, après $8 \mathrm{~h}$, nous avons remarqué une faible diminution de la fluorescence qui s'accentuait pendant les 12 et $24 \mathrm{~h}$ suivantes. Après $24 \mathrm{~h}$ les îlots de Langerhans présentaient un centre complètement dégranulé et seulement quelques cellules halopériphériques réagissaient aux anticorps anti-insuline marqués à la fluorescéine. Inversement l'administration intraveineuse d'anticorps anti-insuline produisait une dégranulation complète après $5 \mathrm{~h}$.

Immunhistologische Untersuchungen Langerhans'scher Inseln zum Nachweis von Insulin nach Stimulation mit Glucose und mit Sulfonylharnstoffen

Zusammenfassung. Die Arbeit schildert zunächst die verschiedenen Möglichkeiten des immunhistologischen Nachweises von Insulin im Pankreas. Als optimale Me. thode zur Aufarbeitung des Gewebes erwies sich die Formalinfixation mit folgender Paraffineinbettung. Die Kryostattechnik liefert unbefriedigende Resultate und eignet sich nur als Screening-Verfahren. Die Gefriertrocknungstechnik mit folgender Paraffineinbettung ist zeitlich recht aufwendig und hat den Nachteil der limitierten Gewebsgröße. Sie bietet dagegen den Vorteil, daß sie die natürlichen Verhältnisse in Zelle und Gewebo am besten bewahrt. - Anschließend wird über die Auswirkungen von Stimulationsversuchen zur Insulinsekretion auf den immunhistologisch nachweisbaren. Insulingehalt der Langerhans'schen Inseln bei der Ratte berichtet. Intravenös injizierte Glucose führt auch in hoher Konzentration $(10 \mathrm{~g} / \mathrm{kg})$ weder nach 2,4 noch nach $24 \mathrm{Std}$ zu einer immunhistologisch nachweisbaren Abnahme des Insulingehaltes der B-Zellen. Nach einmaliger intravenöser Gabe von Tolbutamid $(500 \mathrm{mg} / \mathrm{kg}$ ) sowie von Glybenclamid (1 mg/kg) kam es ebenfalls in den ersten 6 Std zu keiner Verminderung der Immunfluoreszenz der BZellen. Diese zeigt sich erst nach $8 \mathrm{Std}$ an einzelnen Zellen des Inselzentrums, wird deutlicher nach $12 \mathrm{Std}$ in einem größeren Zellbereich und hat nach 24 Std durch Entspeicherung fast aller Zellen mit Ausnahme der Peripherie ihr Maximum erreicht. Im Gegensatz dazu tritt nach intravenöser Injektion von Insulinantikörpern eine nahezu komplette Entspeicherung von immunhistologisch nachweisbarem Insulin bereits nach 5 Std ein.

Key words: B-cells, insulin, immunohistology, freezedrying, formol fixation, insulin secretion, in vivo- in vitro stimulation, sulphonylureas, insulin-antibodies.

\section{Introduction}

Histological procedures have been widely used for the staining of the islets of Langerhans. It is assumed that the staining ability of the beta-cells is correlated with its content of insulin. For example, Pfeiffer et al. (1957) could demonstrate in calves a moderate degranulation of the beta-cells and a hypertrophy of the nuclei following oral tolbutamide application. The histological procedure, however, is disadvantageous 
because cells in other organs can be stained by the same technique, casting some doubt on the specificity of the procedure. On the other hand, with the immunofluorescence technique, using a FITC-labelled antiinsulin-serum, insulin can be definitely detected in the beta-cells of the islets. Lacy and Davies (1957) demonstrated for the first time the ability of insulin to react with the labelled antibody on cryostat tissue sections. In addition to cryotomy, two other methods have been described: freeze-dried and paraffin-embedded materials are ideal for fluorescence microscopy because there is no evidence that immunological properties are altered by freezing and drying or by the short exposure to heat during paraffin-embedding. In addition, freezedried and paraffin-embedded material can be stored for months without any adverse effect on the immunological properties (Neumann, 1958; v. Mayersbach, 1959).

The third method is the use of formalin fixation and paraffin embedding. The reactions of formalin with tissue proteins are numerous and complex, since it can combine with a number of different functional groups. Here, formalin works not only in forming links between adjacent protein chains, but also as a polymerizing fixative. In contrast to a widely held opinion that formalin-fixed tissue is not suitable for fluorescence microscopy, the beta-cells are not significantly altered by these procedures, and insulin can be detected by immunofluorescence in formalin-fixed material (Costanzi et al., 1961; Berns et al., 1962).

This investigation aims at finding the best techniques for the immunohistological detection of insulin in the beta-cells and, with these techniques, studying insulin secretion, using beta-cytropic agents and antiinsulin antibodies.

\section{Materials and Methods}

Animals: 53 male albino rats (Wistar, weighing between 180 to $210 \mathrm{~g}$ ) were used for the beta-cell stimulation of insulin release in vivo, and 8 rats (weighing $300 \mathrm{~g}$ ) for stimulation in vitro. The control group consisted of 10 rats.

\section{A. The following substances were studied:}

\section{Glucose}

10 animals received intravenous injections of $4 \mathrm{ml}$ of a $50 \%$ glucose solution $(10 \mathrm{~g} / \mathrm{kg})$. The animals were killed $90 \mathrm{~min}, 4,8,12$ and $24 \mathrm{~h}$ after the injection.

\section{Glibenclamide ( $\mathrm{Hb}$ 419)}

20 animals were injected with $1 \mathrm{mg} / \mathrm{kg}$ glibenclamide into the upper tail vein, according to the experiment of Kern et al. (1969), and killed after $90 \mathrm{~min}$, 12,24 and $48 \mathrm{~h}$. Blood sugar was determined prior to the injection and at the end of the experiment.

\section{Tolbutamide (Rastinon ${ }^{\circledR}$ )}

$0.5 \mathrm{~g} / \mathrm{kg}$ tolbutamide (Lazarus et al., 1967, Loubatières et al., 1967; Malaisse et al., 1967; Candela, 1967) was given by injection to 16 animals. The rats were killed after $90 \mathrm{~min}, 12,24$ and $48 \mathrm{~h}$. Blood sugar was determined in the same manner as described above.

\section{Guinea pig antiinsulin sera}

7 rats received $2 \mathrm{ml}$ guinea pig antiinsulin serum by continuous infusion over a $4 \mathrm{~h}$ period, or were injected with $0.5 \mathrm{ml}$ antiinsulin serum every hour, for at least $4 \mathrm{~h}$. The titres of the sera were 7290 to 500000 assayed by passive haemagglutination (Stavitsky and Arquilla, 1955), and 1:2000 to 1:500000 assayed by the cellulose adsorption technique according to Kerp et al. (1966). The animals were killed $5 \mathrm{~h}$ after the first injection or initiation of the infusion (Wright, 1959; Cunningham et al., 1963; Gregor et al., 1963; Logothetopoulos et al., 1965; Lacy and Wright, 1965; Wright et al., 1966).

\section{B. Stimulation in vitro of isolated islets of Langerhans}

Islets were isolated from rats according to the method described by Moskalewski (1965), Lacy and Kostianovsky (1967) with small modifications ( $v$. Haugwitz, 1971; Huber, 1971). The islets were cultured in a medium consisting of Krebs-Ringer bicarbonate buffer, supplemented with $2 \mathrm{mg} / \mathrm{ml}$ albumin and equilibrated with $95 \%$ oxygen and $5 \% \mathrm{CO}_{2}$. Tolbutamide was used in a concentration of $500 \mu \mathrm{g} / \mathrm{ml}$ for $1 \mathrm{~h}$ at a temperature of $37^{\circ} \mathrm{C}$. At the end of the culture period, the islets were transferred, with the use of a microscope, to a small test tube and freeze dried.

\section{Immunohistological technique}

\section{a) Cryotomy}

Rats were anaesthetized with nembutal and the pancreas was removed and immediately frozen with $\mathrm{CO}_{2}$, using the system of Dittes - Duspiva. The tissue was sectioned at 4-6 $\mu$, air-dried at room temperature and incubated with labelled antiinsulin globulin in a moist chamber at $37^{\circ} \mathrm{C}$ for $3 \mathrm{~min}$. The sections were then washed 3 times in Mayer's buffer and mounted (Wallace et al., 1950).

\section{b) Preparation of the tissue by freeze drying}

Small pieces of pancreatic tissue, not more than $2 \mathrm{~mm}$ thick, and islets, isolated by means of collagenase, were snap-frozen at $-150^{\circ} \mathrm{C}$ in difluorodichloromethane (Frigen ${ }^{\circledR}$ ) and cooled by liquid nitrogen. The frozen tissues were freeze-dried for $16-18 \mathrm{~h}$ at approximately $5 \times 10^{-2} \mathrm{~mm} \mathrm{Hg}$. When drying was completed, the dried blocks were embedded in paraffin at $65^{\circ} \mathrm{C}$ and at a low pressure of $5 \times 10^{-2} \mathrm{~mm} \mathrm{Hg}$. Sections at $3-5$ microns were mounted without the aid of water and were then taken through xylol, $100 \%$, 
$95 \%$ and $70 \%$ alcohol and phosphate-buffered saline. Staining was carried out, as described above, with labelled antiinsulin globulin.

\section{c) Formalin fixation}

The pancreas was exposed by laparotomy and the tissue was rinsed for a few seconds in normal saline to remove the erythrocytes. Small pieces $\left(0.5 \mathrm{~cm}^{2}\right)$ of pancreas were fixed in $4 \%$ formalin for $12-18 \mathrm{~h}$, with an emulsion consisting of complete Freund's adjuvant (for the first 4 immunizations) and 20 units recrystallized bovine insulin. Four days after each subsequent injection, the guinea-pigs were bled by cardiac puncture. The sera were stored at $-20^{\circ} \mathrm{C}$ until used. Antiinsulin titres were determined by passive haemagglutination, according to the method described by Stavitsky and Arquilla (1955) and by the cellulose adsorption technique (Kerp et al., 1966).

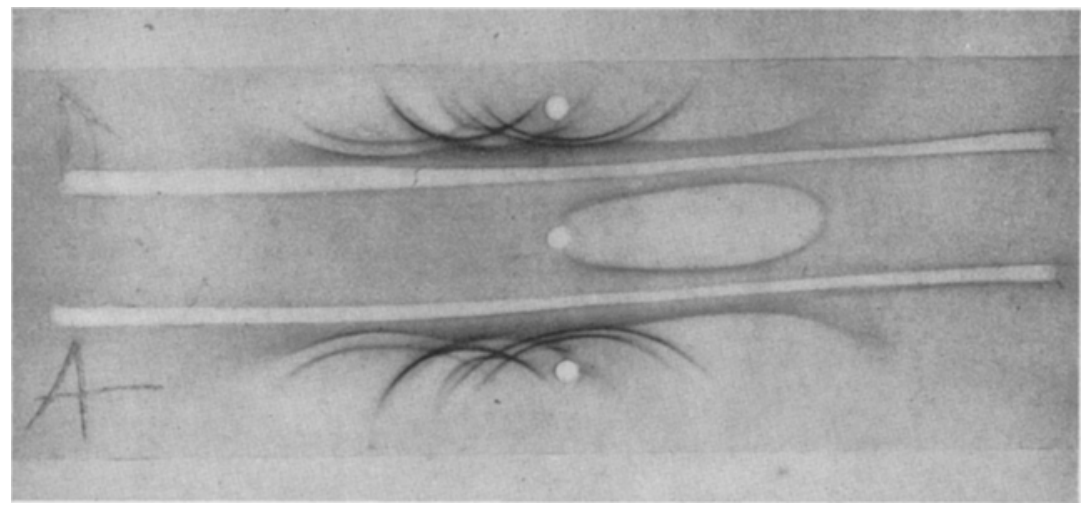

Fig. 1. Immunoelectrophoretic pattern of guinea-pig IgG. Anti-guinea-pig serum was placed in the troughs, normal guinea-pig serum in the upper and lower wells and purified serum containing the antiinsulin antibodies in the central well (DEAE-Sephadex chromotography)

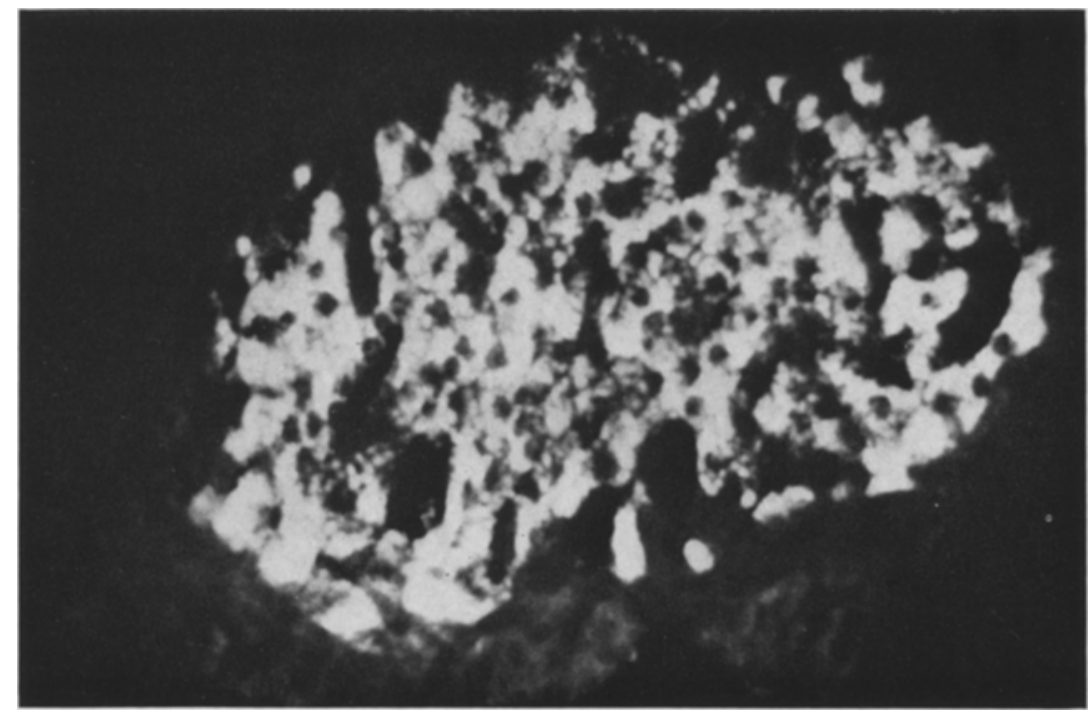

Fig. 2. Freeze-dried islets in pancreatic tissue. Stained with FITC-labelled insulin-antibodies. Note the granular pattern of the fluorescence

dehydrated in alcohol and embedded in paraffin. Sections at $3-5 \mu$ were mounted without the aid of water. They were then taken through xylol, 100\%, $95 \%$ and $70 \%$ alcohol and water. Staining and mounting was again carried out as described above.

\section{d) Production of antiinsulin serum}

The antiinsulin sera were obtained from guinea pigs injected subcutaneously at weekly intervals
Only sera having a haemagglutination titre between 7290 and 590000 or a $50 \%$ affinity of 1 unit ${ }^{131}$ I-labelled insulin at a concentration between 1:2000 and $1: 500000$ were used in our study.

\section{e) Preparation of the FITC-labelled antiserum}

The globulin fraction of the immune sera was obtained by DEAE-Sephadex A 50 chromatography, using phosphate buffer 0.02 molar, pH 7.4. The 
fractions were concentrated by ultrafiltration to a protein content of $20 \mathrm{mg} / \mathrm{ml}$. Immunoelectrophoresis, using veronal buffer, pH 8.6, produced one band for $\operatorname{IgG}$ globulin (Fig. 1). The fractions were labelled with fluoresceinisothiocyanate (FITC), according to the method of Rinderknecht (1962), using $0.1 \mathrm{mg}$ FITC on celite per mg protein. The unreacted fluorescein was removed, and the optimally labelled conjugates were obtained by DEAE-Sephadex chromatography, using a phosphate buffer of $0.01-0.06$ molar, $\mathrm{pH} 7.4$. The dye concentration of conjugates was determined the immunohistological procedures, only fractions with a $\mathrm{F} / \mathrm{P}$ ratio of $0.8-1.5$ were used.

\section{Results}

A. Immunohistological patterns of the islets of Langerhans, using cryotomy, freeze drying and formolfixation.

Sections obtained by cryotomy were usually of minor quality. Cell membranes and nuclei could frequently not be distinguished, and the islets were occasionally surrounded by a fluorescing ring. Even
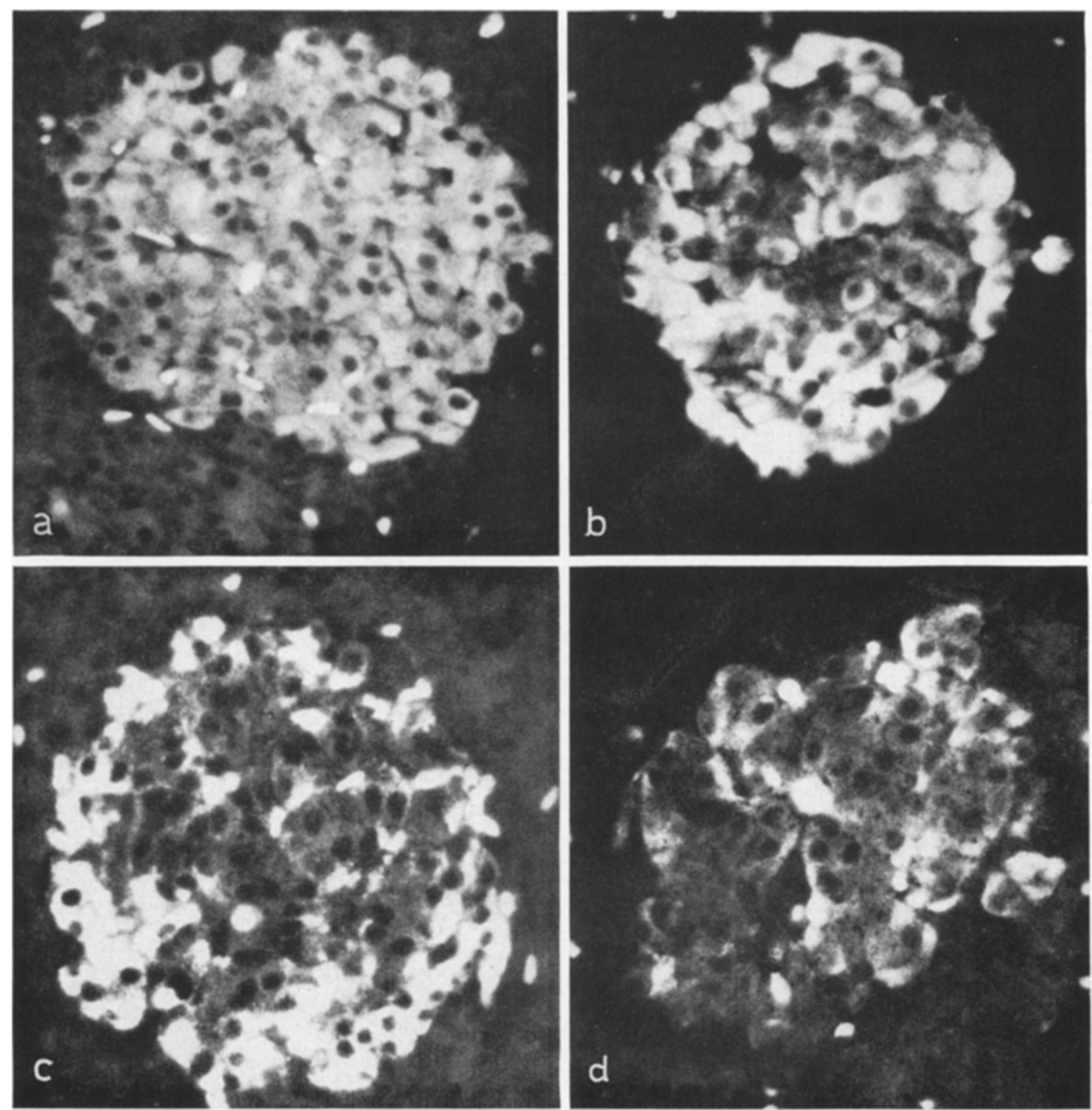

Fig. 3. Formol fixation of pancreatic tissue. Same staining as in Fig. 2. Note the homogeneous pattern of the fluorescence

a) Untreated rat. b) $8 \mathrm{~h}$ after the intravenous administration of glibenclamide, $1 \mathrm{mg} / \mathrm{kg}$. c) $12 \mathrm{~h}$ and $\mathrm{d}$ ) $24 \mathrm{~h}$ after glibenclamide application.

by optical density at the absorption maximum of bound dye $(495 \mathrm{~nm})$. Protein determination was performed with the colorimetric technique of Lowry et al. (1951). Dye/Protein (F/P) ratios in conjugates were calculated from the values obtained, as described above, according to the formula of Nairn (1964). For using ethanol or acetone before or after the staining procedure, the histological quality could not be improved. Freeze-dried pancreatic tissue showed almost no autofluorescence and therefore the contrast of the fluorescing islets was very intense. Cell membranes and nuclei were well separated, and the fluorescence 
usually showed a more granular pattern (Fig. 2). After formol fixation the cytoplasma of the cells showed a homogeneous fluorescence. The nucleus was well defined, and the A-cells could be easily distinguished as a dark area at the islet periphery. However, we frequently found a strong autofluorescence of the pancreatic exocrine tissue and an orange autofluorescence of the erythrocytes (Fig. 3 a).

\section{Glibenclamide}

No change in fluorescence intensity could be observed in the islets, $90 \mathrm{~min}$ and $4 \mathrm{~h}$ after the application of glibenclamide, even though blood glucose levels decreased from the normal of $120 \mathrm{mg} \%$ to $60 \mathrm{mg} \%$. The first decrease in fluorescence became apparent after $8 \mathrm{~h}$ (Fig. $3 \mathrm{~b}$ ). Twelve hours after the single injections of glibenclamide, the insulin content of the

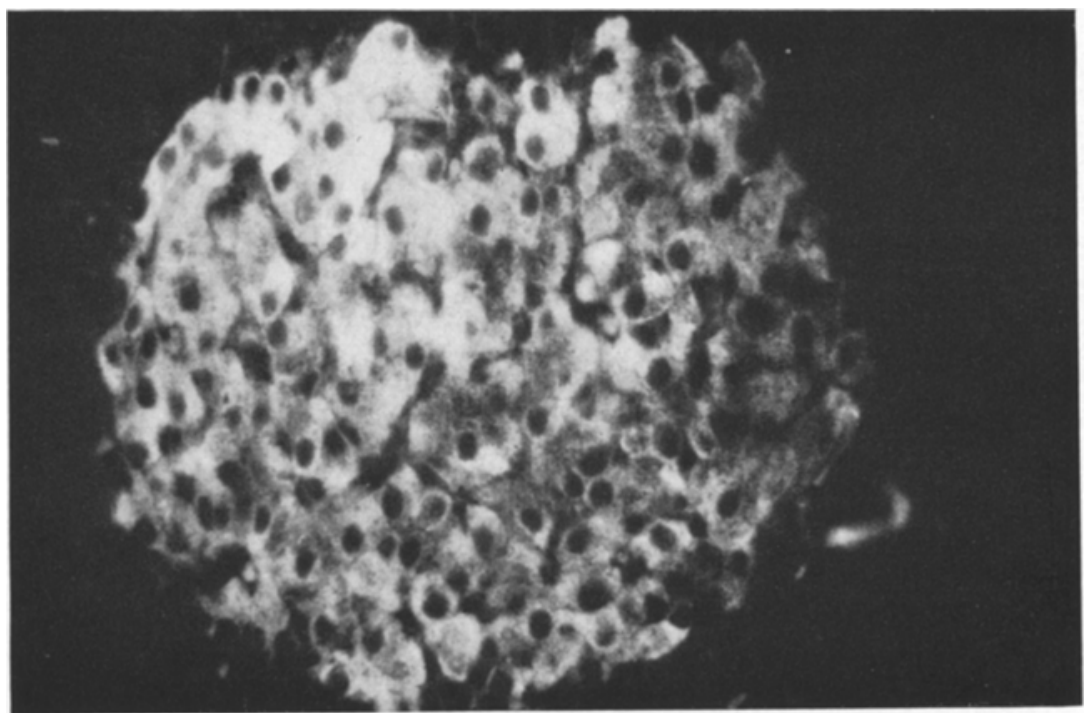

Fig. 4. $48 \mathrm{~h}$ after the single intravenous injection of glibenclamide (1 $\mathrm{mg} / \mathrm{kg}$ ). Note the increase in fluorescence (Formalin-fixed tissue)
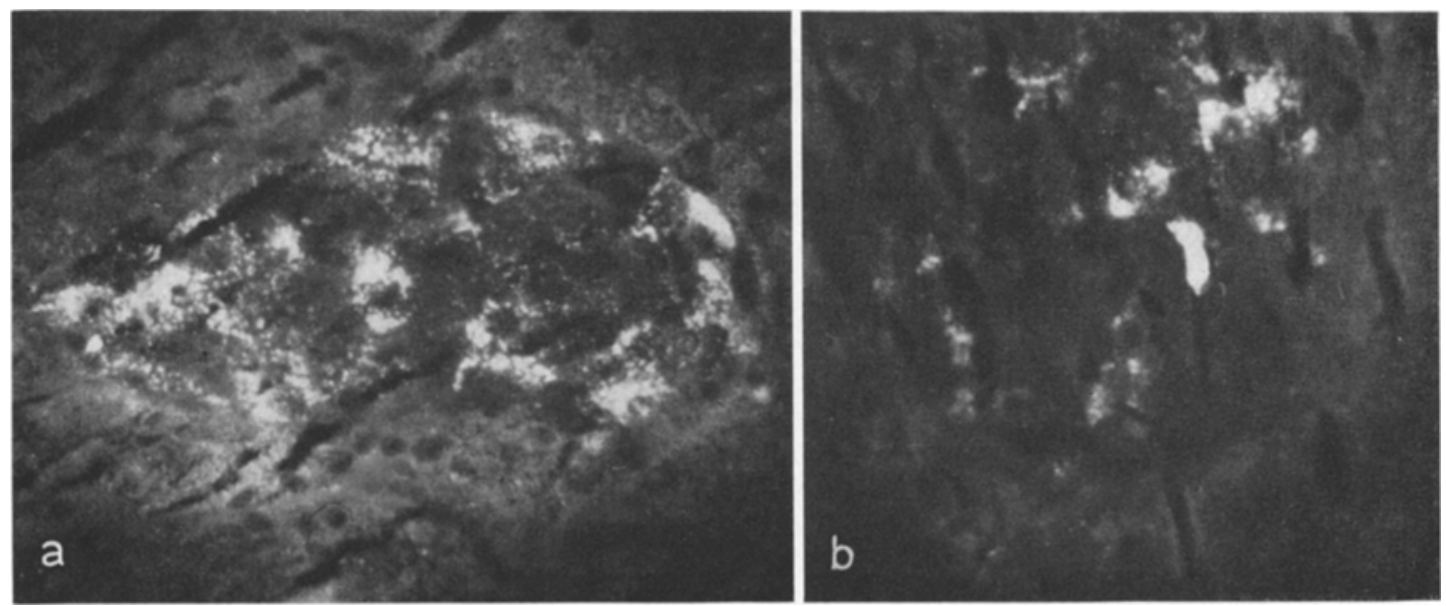

Fig. 5. a) $5 \mathrm{~h}$ after the intravenous injection of $2 \mathrm{ml}$ of insulin-antibodies (titre $1: 21810$ )

b) After the injection of a potent anti-insulin serum (titre 1:590000). Almost complete degranulation, with a few fluorescing cells at the periphery (freeze-dried islets)

B. Immunohistological patterns of the islets of Langerhans after stimulation in vivo, using freeze drying and formalin fixation.

\section{Glucose}

There was no decrease in fluorescence in the betacells of rats, $90 \mathrm{~min}, 4,8,12$ and $24 \mathrm{~h}$ after the injection of glucose. beta-cells was clearly diminished. Areas with heavily degranulated beta cells were confined to the centre of the islets, surrounded by almost normally stained beta cells (Fig. $3 \mathrm{c}$ ).

\section{Tolbutamide}

The single intravenous injection of $0.5 \mathrm{~g} / \mathrm{kg}$ did not show a detectable effect on the insulin content of the 
beta cells of the rats after 90 min and $4 \mathrm{~h}$. Despite the decrease in blood sugar from 140-120 $\mathrm{mg} \%$ to $80-70 \mathrm{mg} \%$, there was no decrease in fluorescence. However the fluorescence was clearly diminished when examined after $12 \mathrm{~h}$, and the maximum decrease in fluorescence was $24 \mathrm{~h}$ after the application (Fig. $3 \mathrm{~d}$ ). The increase of the content of insulin in the beta cells, as detected by immunofluorescence, could be observed after $48 \mathrm{~h}$ (Fig. 4).

\section{Antiinsulin serum}

Five hours after initiation of the infusion or after the first injection, the islets of the rats showed aImost a complete decrease in fluorescence. The islets showed the same pattern of fluorescence described 12 and $24 \mathrm{~h}$ after glibenclamide or tolbutamide injection. The centre of the islets did not have fluorescence, and appeared in a manner almost identical to the autofluorescence seen in unstained preparations, and only a few fluorescing cells were situated peripherally. However, when very potent sera (haemagglutination titres $1: 590000$ ) were used, the islets were completely dark, showing no fluorescence. Blood glucose levels in most of the rats treated with antibodies were close to $350 \mathrm{mg} \%$ at the end of the fifth hour, when the rats were killed (Figs. 5a and b). pancreatic tissue. The fluorescence was as dense and homogeneous as that observed in formol-fixed material. A decrease in fluorescence in the tolbutamide treated islets could not be observed (Fig. 6), in spite of the fact that the immunologically measurable insulin (IMI) increased in the culture media (Huber, 1971). These findings support the results obtained after stimulation in vivo: there is no decrease in fluorescence during the first few hours.

\section{Discussion}

The present results confirm earlier reports (Lacy and Davies, 1957) which state that the dynamics of insulin secretion on a morphological basis can be studied by immunofluorescence as well as by usual histological staining methods. Although unfixed cryotome sections have been widely employed in immunofluorescence for the demonstration of insulin in the islets of Langerhans, it must be emphasized, that the only advantage of this technique is the rapid, simple preparation of the tissue. However the sections are usually $5-7 \mu$ in thickness and the staining of minor quality. Freeze drying is almost ideal, and the stained slides are of good quality. In this case however, the tissue pieces

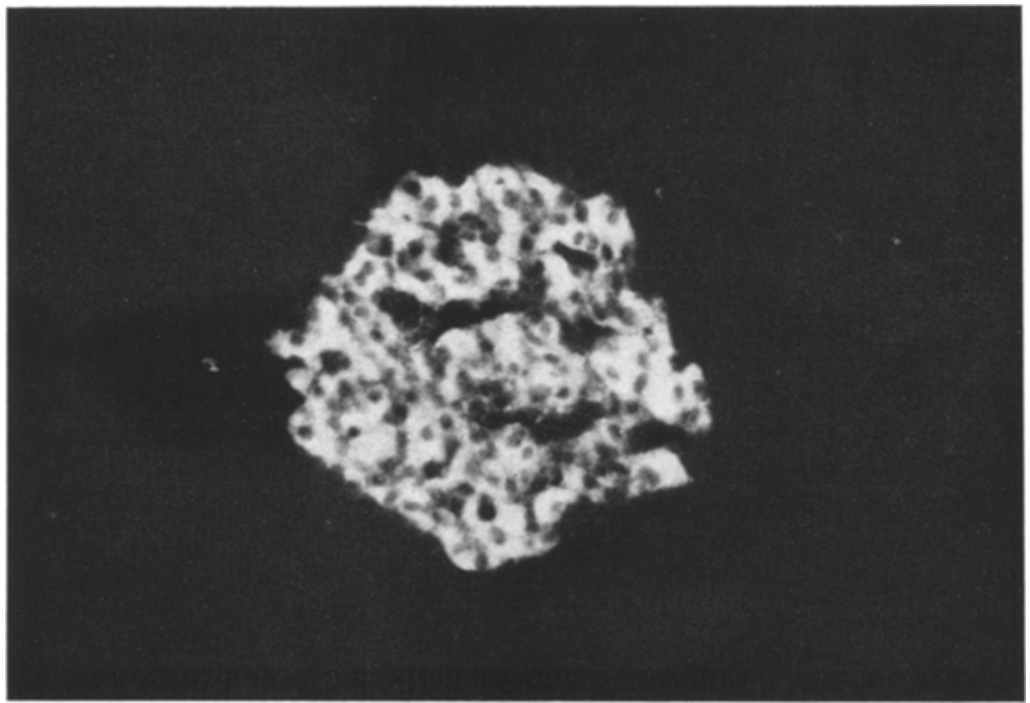

Fig. 6. Isolated islet. Incubation with $500 \mu \mathrm{g} / \mathrm{ml}$ tolbutamide for one hour did not reduce the fluorescence intensity (Freeze-dried islet)

C. Immunohistological patterns of the isolated islets after stimulation in vitro, using the freeze drying technique.

A series of cultures ( 40 islets in each) from 8 animals were prepared and examined subsequently. Sections for immunohistology were prepared from the cultured, freeze-dried and paraffin-embedded islets. Incubation. of the sections with FITC-labelled antiserum produced. a green, homogeneous fluorescence of the islets, surrounded in some instances by non-fluorescing exocrine must be small and the technique is extremely time consuming. Costanzi et al. (1961) were the first to report that formalin fixation does not significantly alter the ability of the beta granules to bind with antiinsulin serum.

Formalin fixation produces a more dense and homogeneous fluorescence of the beta cells than that found in freeze dried tissue preparations, where insulin is also present in a granular form. This homogeneous fluorescence in the formalin-fixed material 
may be caused by the polymerizing effect of formalin.

Mechanisms of insulin secretion have been widely studied by means of tolbutamide, using histological staining procedures. However, using an aldehydefuchsin staining procedure, cells other than those of the islets, e.g. in the pancreatic ducts, can also be stained. Therefore the use of purified and optimally labelled antiinsulin sera is advantageous in possessing a higher degree of specificity.

First experiments to study the secretion of insulin in rats after oral application of tolbutamide $(50 \mathrm{mg} / \mathrm{kg})$ were done by Bänder et al. (1957). They found that a reduction in granulation became apparent $30 \mathrm{~min}$ after the application, and that after $6 \mathrm{~h}$ the granule content had been decreased to $25 \%$ of its original value. Six hours after application of $2000 \mathrm{mg} / \mathrm{kg}$, degranulation proceeded in the same manner, reducing the granule content to one quarter of the original. However, after a period of $24 \mathrm{~h}$ examination of the islets disclosed full degranulation of betacells, and a return of the islet cell system to its normal granulation density was not to be seen until $96 \mathrm{~h}$ after tolbutamide administration.

With the oral administration of $5 \mathrm{mg} / \mathrm{kg}$ glibenclamide in rats, Bänder et al. (1969) found an initiation of degranulation of the beta-cells after $4 \mathrm{~h}$. The decrease amounted to about $50 \%$ of the initial content after $8 \mathrm{~h}$, and was followed by an almost complete degranulation after $24 \mathrm{~h}$. At this time, Kellner et al. (1969) still found sulphonylureas in the blood using ${ }^{14} \mathrm{C}$-labelled glibenclamide $(0.2 \mathrm{mg} / \mathrm{kg})$. Therefore it must be postulated that this slow but progressive degranulation is the result of the continuous stimulating effect of sulphonylureas. With the electron microscopic technique the degranulation following glibenclamide application became apparent only after $6-8 \mathrm{~h}$ (when using 10 or 20 times the minimal effective dose) and was fully developed after $12-24 \mathrm{~h}$ (Kern et al., 1969). The authors found the degranulation to occur most frequently in the central portion of the islets. These reports support our results obtained with the immunofluorescence technique. Even high doses of glibenclamide $(5 \mathrm{mg} / \mathrm{kg})$ were not able to produce a decrease in fluorescence in the islets after $90 \mathrm{~min}$, although blood glucose levels were clearly reduced. The same results were obtained using isolated islets. After an incubation time of 90 minutes with tolbutamide, no decrease in fluorescence could be observed. These findings, however, do not exclude the possibility of quicker secretion of insulin by the beta cells. This could be demonstrated with intravenously injected antiinsulin-serum, in which instance a decrease in fluorescently stained insulin in the centre of the islets could be observed after $5 \mathrm{~h}$. At this time, brilliantly fluorescing beta cells could be observed only in the islet periphery.

Previous studies (Logothetopoulos et al., 1965) comparing degrees of degranulation showed a much greater loss of granules after the application of insulin antibodies, than after infusion of glucose alone or in combination with hydroxybutyrate and acetoacetate. Thus they would suggest that circulating excess antibody will effectively bind insulin where it is present along the entire length of the sinusoids of the islets, establishing an effective diffusion gradient for insulin from the beta-cells or from extracellular space.

Our own experiments, attempting to demonstrate the injected antibody on the surface of B-cells or its binding by beta granules failed. Even FITC-labelled antibodies injected in vivo could not be detected in the islets. On the other hand, Blumenthal et al. (1964) demonstrated in chicken embryo by fluorescence microscopy that the injected antiinsulinglobulin entered the B-cells and was here bound by the beta-granules. Moreover, Lacy and Wright (1965) had observed that the intravenous or intraperitoneal injection of serum containing antibodies to bovine insulin, was followed by an acute form of allergic pancreatitis, indicating that the injected antibodies reach the insulin-producing cells and cause some form of damage. Numerous morphological examinations have shown that insulin released during the first few hours after application of sulphonylureas is too low to cause a visible loss of insulin when examined by light or electron microscopy.

These results suggest that the insulin released immediately is not stored in granules and cannot be detected by histology, immunohistology or electron microscopy. The current immunohistological studies corroborate the electron microscopic observations of Kern et al. (1969) that B-cells contain insulin in two different forms. One form, which may be free in the cytoplasm is released as a rapid expulsion within a few minutes. The second is released more leisurely from granules providing that the stimulating effect of the sulphonylureas is active over a longer period of time. So far, the two compartment model of Grodsky et al., (1967) would find some morphological correspondence, although another experimental model with other time conditions was used. The immunohistological technique is undoubtedly of greater value for further morphological investigations employing specifie antibodies against insulin precursors than is the normal histological procedure.

\section{References}

Bänder, A., Pfaff, W., Ritter, K., Wohlfahrt, A., Schmidt, F.H.: Zur Pharmakologie von HB 419. Tegernsee-Konferenz über das neue orale Antidiabetikum HB 419 (27. 1. bis 29 . 1. 1969).

- - Schessmer, G.: Lichtoptisch-morphologische Untersuchungen an der B-Zelle der Langerhans'schen Insel nach Verabreichung von HB 419. Arzneimittelforschung 19, 1448-1451 (1969).

- Häussler, A., Scholz, J.: Ergänzende pharmakologische Untersuchungen über Rastinon. Dtsch. med. Wschr. 82, 1557-1558 (1957).

Berns, A. W., Hirata, Y., Blumenthal, H.T.: Application of fluorescence microscopy to the study of possible in- 
sulin-binding reactions in formalin fixed material. $J$. Lab. clin. Med. 60, 535-551 (1962).

Blumenthal, S.D., Berns, A.W., Blumenthal, H.T.: Antiinsulinserum effects on islets of Langerhans of chick embryo. Arch. Path. 77, 107-112 (1964).

Candela, J.L.R. : Insulin secretion in vivo and in vitro. In: The structure and metabolism of the pancreatic islets, p. 349. Herausg.: Brolin, S.E., Hellman, B., Knutson, H. Oxford: Pergamon Press 1964,

Coons, A.H., Kaplan, M.H.: Localization of antigen in tissue cells. J. exp. Med. 91, 1-13 (1950).

Costanzi, C., Mancini, A.M., Zampa, G.A.: Ricerche Sperimentali sugli anticorpi insulinici. III. Immunoistologia del pancreas endocrino con siero di cavia antiinsulina bocina, coniugato isotiocianato di fluorescina. Boll. Soc. ital. Biol. Sper. 37, 1233-1235 (1961).

Cunningham, N.F., Patterson, D.S.P., Wright, P.H.: Acute insulin deficiency provoked in sheep and cows by single injections of anti-insulin serum. J. Physiol. (Lond.) 169, 137-148 (1963).

Findlay, J.A., Gill, J.R., Irvine, G., Lever, J.D., Randle, P.J.: Cytology of beta cells in rabbit pancreas pieces incubated in vitro; effects of glucose and tolbutamide. Diabetologia 4, 150-160 (1968).

Gregor, W.H., Martin, J.M., Williamson, J.R., Lacy,P. E., Kipnis, D.M.: A study of the diabetic syndrome produced in rats by anti-insulin serum. Diabetes $\mathbf{1 2}$, $73-81(1963)$

Grodsky, G.M., Bennet, L.L., Smith, D., Nemechek, K.: The effect of tolbutamide and glucose on the timed re. lease of insulin from the isolated perfused pancreas. Tolbutamide.... after ten years, p. 11. Editors: Butterfield, W.J.H. and Westering, W.V., Excerpta Medica Foundation Amsterdam 1967.

Haugwitz, M.v.: Inaugural-Dissertation, Ulm 1971. In preparation.

Huber, V.: Untersuchungen zur Insulinfreisetzung isolierter Langerhans'scher Inseln der Ratte nach Inkubation mit Glucose und Sulfonylharnstoffen. Inaugural Dissertation, Ulm 1971.

Kellner, H.M., Christ, O., Rupp, W., Heptner, W.: Resorption, Verteilung und Ausscheidung nach Gabe von ${ }^{14} \mathrm{C}$-markiertem HB 419 an Kaninohen, Ratten und Hunden. Arzneimittelforschung 19, Suppl. 1388-1400 (1969).

Kern, H.F., Kern, D., Schmidt F.F., Stork, H.: The fine structure of the islets of Langerhans in rats and rabbits after treatment with Glibenclamid (HB 419). Hormone and Metabolic Research, Suppl. I, 11, 1969.

Kerp, L., Steinhilber, S., Kasemir, H.: Ein Verfahren zum Nachweis insulinbindender Antikörper durch Differentialadsorption. Klin. Wschr. 11, 560-567 (1966)

Lacy, P.E., Davies, J.: Preliminary studies on the demonstration of insulin in the islets by fluorescent antibody technique. Diabetes 6, 354-357 (1957).

- Kostianovsky, M.: Method for the isolation of intact islets of Langerhans from the rat pancreas. Diabetes $\mathbf{1 6}$, $35-39(1967)$

- Wright, P.H. : Allergic interstitial pancreatitis in rats injeoted with guinea pig anti-insulin serum. Diabetes 14, 634-642 (1965)

Lazarus, S.S., Brancato, P., Shapiro, S., Volk, B.W.: Cytology of insulin secretion in rabbit. In: Tolbutamide ... after ten years, p. 83. Editors. : Butterfeld, W.J.H. and $v$. Westering, W. Amsterdam: Excerpta med. Found. 1967.

Logothetopoulos, J., Davidson, J.K., Haist, R.E., Best, C. H. : Degranulation of beta cells and loss of pancreatic insulin after infusions of insulin antibody or glucose. Diabetes 14, 493-500 (1965).
Loubatières, A., Mariani, M.M., Alric, R., Chapal, J. Antagonistic mechanism of actions of Tolbutamide and Diazoxide on insulin secretion. In: Tolbutamide ... after ten years, p. 100. Herausg.: Butterfield, W.J.H. and Westering, W. v. Amsterdam: Excerpta med. Found. 1967.

- Ribes, G., Malbosc, H. de, Alric, R., Chapal, J. Pharmakologische Untersuchungen eines neuen hoch wirksamen blutzuekersenkenden Sulfonamids, des Glibenclamid (HB 419). Arzneimittelforschung 19, $1354-1363$ (1969).

Lowry, O.H., Rosebrough, N.J., Farr, A.L., Randall, R.J.: Protein measurement with folin phenol reagent. J. biol. Chem. 193, 265-275 (1951)

Malaisse, W.J., Malaisse-Lagae, F., Mayhew, D.A. Wright, P.H.: Effects of sulfonylureas upon insulin secretion by the rat pancreas. In: Tolbutamide ... after ten years p. 49. Editors.: Butterfield, W.J.H. and Westering, W. v. Amsterdama: Excerpta med. Found. 1967.

Mayersbach, H. von: Die Anwendung der Gefriertrocknung für die Immunhistologie. Acta histochem. 8 $524-534(1959)$

Moskalewski, S.: Isolation and culture of the islets of Langerhans of the guinea pig. Gen. Comp. Endocr. 5, $342-353(1965)$

Neumann, K.H.: Anwendung der Gefriertrocknung für histochemische Untersuchungen. In: Handbuch der Histochemie, S. 1. Herausg. : Graumann, W., Neumann, K.H. Stuttgart: G. Fischer Verlag 1958.

Nairn, R.C.: Fluorescent protein tracing. Edinburgh and London: E. \& S. Livingstone Ltd. 1964.

Pfaff, W., Schöne, H.H.: Zur Insulinfreisetzung aus Pankreas durch Sulfonylharnstoffe. Arzneimittelforschung 19, 1445-1448 (1969).

Pfeiffer, E.F., Steigerwald, H., Sandritter, W., Bänder, A., Mager, A., Becker, U., Retiene, K.: Vergleichende Untersuchungen von Morphologie und Hormongehalt des Kälberpankreas nach Sulfonylharnstoffen (D 860). Dtsch. med. Wschr. 82, 1568-1574 (1957).

Rinderknecht, H.: Ultra-rapid fluorescent labeling of Proteins. Nature 193, $167-168$ (1962).

Stavitsky, A. B., Arquilla, E. R.: Production and application of hemagglutination and hemagglutination inhibition reactions with bis-diazotized benzidine and protein-conjugated red-blood cells. J. Immunol. 74, 306$312(1955)$.

Wallace, A.L., Osler, A.G., Mayer, M.M.: Quantitative studies of Complement-Fixation J. Immunol, 65, 661 $673(1950)$

Wrenshall, G.A., Collins-Williams, J., Hartroft, W.S.: Incidence, control and regression of diabetic symptoms in the alloxan-treated rat. Amer. J. Physiol. 156, $100-$ 113 (1949).

Wright, P.H.: Production of acute insulin defieiency by administration of insulin antiserum. Nature 183, 829 $830(1959)$

- Rivera-Calimlim, L., Malaisse, W.J.: Endogenous insulin secretion in the rat following injection of anti-insulin serum. Amer. J. Physiol. 211, 1089-1094 (1966).

Doz. Dr. K. Federlin,

Section of Clinical Immunology,

Department of Endocrinology

and Metabolism,

Center of Internal Medicine

and Pediatries,

University of UIm,

D-7900 Ulm/Donau

Germany 